\title{
COMMENTARY: The Use of Focus Groups for Design and Implementation of Collaborative Environmental Administrative Programs: A Comparison of Two State-Level Processes in Ohio
}

Wendy Kellogg

Cleveland State University, w.kellogg@csuohio.edu

Kevin E. O'Brien

Cleveland State University, k.e.obrien@csuohio.edu

Claudette Robey

Cleveland State University, c.robey@csuohio.edu

Eollow this and additional works at: https://engagedscholarship.csuohio.edu/urban_facpub

Part of the Environmental Policy Commons, and the Urban Studies and Planning Commons How does access to this work benefit you? Let us know!

\section{Publisher's Statement}

(c) 2007 Cambridge University Press

\section{Original Citation}

Kellogg, W. A., O'Brien, K., Robey, C., \& Toth, K. (January 01, 2007). COMMENTARY: The Use of Focus Groups for Design and Implementation of Collaborative Environmental Administrative Programs: A Comparison of Two State-Level Processes in Ohio. Environmental Practice, 9, 3, 166-178.

\section{Repository Citation}

Kellogg, Wendy; O'Brien, Kevin E.; Robey, Claudette; and Toth, Kirstin, "COMMENTARY: The Use of Focus Groups for Design and Implementation of Collaborative Environmental Administrative Programs: A Comparison of Two StateLevel Processes in Ohio" (2007). All Maxine Goodman Levin School of Urban Affairs Publications. 012363. https://engagedscholarship.csuohio.edu/urban_facpub/63

This Article is brought to you for free and open access by the Maxine Goodman Levin School of Urban Affairs at EngagedScholarship@CSU. It has been accepted for inclusion in All Maxine Goodman Levin School of Urban Affairs Publications by an authorized administrator of EngagedScholarship@CSU. For more information, please contact library.es@csuohio.edu. 


\section{The Use of Focus Groups for Design and Implementation of Collaborative Environmental Administrative Programs: A Comparison of Two State-Level Processes in Ohio}

\author{
Wendy A. Kellogg, Kevin O’Brien, \\ Claudette Robey, Kirstin Toth
}

Development and implementation of administrative programs are important steps in the process of change through public law and policy. These programs set the specific mechanisms that will be used to carry out the intent of the law or policy as best an agency can determine. Administrative personnel may involve the general public and stakeholders in program development and implementation in order to improve program design, increasingly used as part of collaborative environmental management strategies. This article examines the use of focus groups as a stakeholder participation method in collaborative program development and implementation processes in two different environmentallyoriented agency programs at the state level in Ohio-the Clean Ohio Revitalization Fund of the Ohio Department of Development, and the Ohio Coastal Resources Management Training Program of the Ohio Department of Natural Resources, NOAA, and the Ohio Sea Grant Program. The comparison confirms three categories of benefits in using focus groups: better program development and implementation through more in-depth and nuanced information from stakeholders, an enhanced administrative and civic capacity through development of a shared knowledge base, and an enhanced sense of legitimacy for the program among future program beneficiaries. The comparison also identified some constraints and challenges for using focus groups, including the importance of skilled facilitators with substantive knowl- edge of the environmental context of the program development process and the skills to resolve contentious stakeholder interactions when the processes are distributive in nature.

Environmental Practice 9:166-178 (2007)

\section{Toward Collaborative Environmental Management}

D evelopment and implementation of administrative programs are important steps in the realization of change through public law and policy. These programs set the specific mechanisms that will be used to carry out the intent of the law or policy as best an agency can determine (Spicer and Terry, 1996). Administrative programs are derived from statute, but their design and application are shaped by agency culture and practice (Meidinger, 1987; Reich, 1985). Beginning in the 1960s, administrative personnel were urged to involve the general public and stakeholders in program development and implementation. These stakeholders have included citizens, economic actors, local decision makers, and other sectors of the general public who either will be affected by policy implementation or who will shape implementation at some point (Desario and Langton, 1987; Kellogg, 1998; Kweit and Kweit, 1981; Nichols, 2002). Today, environmental problems have become more intractable and problem resolutions appear to lie across multiple environmental resources, stakeholders, and institutions. As the nature of the problems addressed by administrative agencies has changed, so has the organizational structure required to address them (Booher, 2004; Heikkila and Gerlak, 2005; Randolph, 2004).

Affiliation of authors: Wendy A. Kellogg, Center for Planning Research and Practice, Levin College of Urban Affairs, Cleveland State University, Cleveland, Ohio; Kevin O’Brien, Great Lakes Environmental Finance Center, Levin College of Urban Affairs, Cleveland State University, Cleveland, Ohio; Claudette Robey, Great Lakes Environmental Finance Center, Levin College of Urban Affairs, Cleveland State University, Cleveland, Ohio; Kirstin Toth, Great Lakes Environmental Finance Center, Levin College of Urban Affairs, Cleveland State University, Cleveland, Ohio

Address correspondence to: Wendy A. Kellogg, Director, Center for Planning Research and Practice, Levin College of Urban Affairs, Cleveland State University, 1717 Euclid Ave., Cleveland, $\mathrm{OH}$ 44115; (e-mail) wendy@urban.csuohio.edu.

(C) 2007 National Association of Environmental Professionals 
As Booher notes (2004), traditional approaches under conditions of clear agency hierarchy and single resource mandates have shifted toward loosely configured collaborative arrangements addressing interdisciplinary problems. Newman et al. (2004) attribute the trend toward collaborative governance to the inadequate agency capacities in the realm of "project politics," focused on resolving issues of local concern.

The practice of stakeholder involvement is now several decades old, and the potential benefits from the use of more collaborative management processes are well documented: shared information to build understanding between the agency and the public about their roles and expectations; wiser decisions and support for them by resolving disputes; improved program effectiveness by mobilizing resources and sharing management responsibilities; and capacity-building among agencies, organizations, and communities (Connick and Innes, 2003; Heikkila and Gerlak, 2005; Leach, Pelkey, and Sabatier, 2002; Wondolleck and Yaffee, 2000). Collaborative processes can accrue these benefits in part because the participation of stakeholders occurs much earlier in the governance process, brings together a wider range of interests, and tends to favor face-to-face discussions (Koontz and Johnson, 2004).

Here, we are interested in the benefits accrued from the involvement of stakeholders in program development, which in total result in more effective programs because public managers receive better input as to the appropriate role for agency and needs of program beneficiaries (Nichols, 2002; Spicer and Terry, 1996; Thomas, 1993), generate enhanced knowledge for development of better programs (Desario and Langton, 1987; Kellogg, 1998; Vroom and Yetton, 1973), generate legitimacy among stakeholders and the public (Harter, 1982; Wondolleck and Yaffee, 2000), reduce conflict (Nichols, 2002), and build a constituency for the outcomes of the program (Barber, 1981; Fischer, 1993; Rich, 1986). This "consensus-rulemaking" (Booher, 2004, p. 37) or "interactive decision making" (Edelbos and Klijn, 2005) involves stakeholders' coproduction of the agency program and its implementation mechanisms (Cooper and Kathi, 2005).

A variety of mechanisms can be used to involve stakeholders, ranging from large public meetings to smallgroup, advisory bodies, or taskforces (Desario and Langton, 1987; Kweit and Kweit, 1981; Randolph, 2004). The particular mechanism chosen for stakeholder involvement de- pends on the administrative needs of the program. Generally, the more contested and complex the environmental management problem, the more small groups of stakeholders, rather than large public meetings, are appropriate or typically used (Koontz and Johnson, 2004). This article examines the use of one stakeholder involvement technique, the focus group. In public sector policy and in administrative contexts, focus groups have been used to facilitate communication between policy organizations and publics (Grunig, 1992), as part of a policy analysis process (Kahan, 2001), and to design implementation programs (Kellogg et al., 2005; Nichols, 2002). In environmental governance, focus groups can be an important component of administrative practice, given the greater flexibility and "stakeholder-sensitive" regulatory frameworks that characterize administrative practice today (Durant et al., 2004, p. 647).

We present two case study applications of the use of focus groups in the program development and implementation process for two different environmentally-oriented agencies at the state level in Ohio-the Ohio Department of Development, lead agency for administration of the Clean Ohio Revitalization Fund, a program that finances cleanup and redevelopment of environmentally-contaminated properties; and the Ohio Department of Natural Resources, a partner in the Ohio Coastal Resources Management Training Program. In the first application, the agency was developing the administrative rules and program that would be used to implement legislation. In the second application, the focus groups were used to gather information for a strategic planning process that implemented administrative requirements of a federal agency. In both cases, however, the focus groups consisted of stakeholders who would eventually benefit from the program (in terms of enhanced knowledge and program funding) and who had technical expertise.

The remainder of the article first describes focus groups as an applied, collaborative co-production method. It then provides a brief description of the setting for the two agency programs. We then describe how the focus groups were used in these two applications to gather information needed for program development and implementation. Finally, key lessons learned from a comparison of these two applications are discussed. Our purpose is to assess whether the purported benefits of a collaborative approach to program design were realized in these two environmental settings and what constraints were present that shaped the use of focus groups in each. 


\section{The Focus Group as a Setting for Collaborative Program Development and Implementation}

The focus group technique has evolved from its first application in the business or political world, where it had been used most frequently as part of a marketing strategy and in political campaigns for public relations (Bellinger, Bernhardt, and Goldstucker, 1976; Higgenbotham and Cox, 1979). Its use as a research technique was then expanded into the social sciences (Wilkinson, 1998), the medical and psychological professions (Dreachslin, 1999; Grunig, 1992), and environmental studies fields (Desvousges and Smith, 1988; Kaplowitz and Hoehn, 2001).

The focus group offers a setting in which stakeholders get a chance to explore what they and their colleagues perceive about a specific situation in an interactive environment that enables people to listen and reflect on their own experiences and the opinions of others (Kellogg et al., 2005; Kreuger, 1994; Kreuger and Casey, 2000). Focus groups can be understood as a multi-dimensional process of communication. The information includes data from the oral (and perhaps written) communication of individuals to the agency and from the communication of information by members to each other. Participants not only say words, they communicate meaning, influencing each other toward shared understanding and meaning that becomes apparent through the social interaction (Albrecht, Johnson, and Walther, 1993). Through this interaction, the agency can tease out the various interpretations of "policy language, legislative intent, and implementing actions" brought to the process by different sets of stakeholder participants (Yanow, 1993, p. 42). These interpretations reflect what Polanyi (1966) called "tacit knowledge" - the background theories from which actors interpret policy objectives, ends, and means (Grin and Van de Graaf, 1997). Facilitators, therefore, must design and "run" the focus group to allow stakeholder participants to not only provide their perspectives, but to interact sufficiently to allow for concurrent interpretations of the agency's proposed programs or needs. Facilitators need to control any potential dominance of discussion by single individuals by using techniques related to structured exercises, written responses, use of the same facilitator across sessions, and quantitative measures such as short surveys against which results can be tested (Albrecht, Johnson, and Walther, 1993).

The makeup of focus group participants depends in large part upon the purpose of the exercise and the information needed. Ideally, the members of a focus group are charac- terized by relative homogeneity (i.e., they share common traits of interest to the researcher), but with enough variation-either within the group or across several groups-to allow for identification of consensus and contrasting opinions (Kahan, 2001; Kreuger and Casey, 2000). Focus groups are constituted according to a set of control characteristics (common to all groups) and/or break characteristics (differentiating the groups from each other). Use of both types of characteristics to designate focus groups generates subsets of participants with potentially contrasting views or experiences and helps verify views or experiences held in common (Knodel, 1993). The target size for a focus group is typically quite small (between eight and 15 participants). The key is to ensure a sufficient number of participants together to generate discussion, while precluding a group that is too large, which can result in a loss of valuable comments unless facilitated carefully (Kreuger, 1994).

Information gained through the deliberative process can and should be accomplished using several different techniques. For oral comments, these typically include one or more of the following: tape recording, real-time typing input of responses, journal notes, and notes on newsprint (primarily so that participants can also keep track of what has been said in discussion). Participants can also provide written data through short surveys either before or after the session and through any notecards used for them to record thoughts during session exercises (Albrecht, Johnson, and Walther, 1993; Kreuger, 1994). Together, these techniques can provide a triangulation of information, generating a more robust accounting of the session. Our sessions used real-time typing, journal entries by observers, and newsprint recording to collect comments. Participants also completed a short questionnaire prior to the focus group session, against which sessions notes were compared.

Analysis of these data sources needs to be systematic to ensure validity and requires judgment by the researcher, in that not all statements can be taken at face value (Knodel, 1993). We included both quantitative (the event-based questionnaire) and qualitative methods for analyzing the data. The latter qualitative analysis consisted of pattern searching for themes (Knodel, 1993; Seidel and Clark, 1984). In order for the qualitative analysis to generate valid results, the facilitation team needs to have a thorough knowledge of the administrative setting, historic context, and scientific or technical topics relevant to the work of the focus groups. The team consisted of research staff and faculty with expertise in public administration and management, 
environmental policy, natural resource science, and public participation methods.

\section{Administrative Program Context}

\section{Clean Ohio Revitalization Fund}

As in many other states in the Great Lakes basin, the decline of Ohio's manufacturing sector has left thousands of industrial and commercial properties abandoned. Many of these properties, due to poor practices prior to environmental regulations of the 1970s, have significant contamination problems, either in soils, groundwater, or in buildings. The severity of contaminants ranges from petroleum products leaking from underground storage tanks to the presence of asbestos, polychlorinated biphenyls (PCBs), or radioactive waste. The vast majorities of sites do not pose an immediate health or ecological risk to warrant emergency cleanup, but often create a significant burden for the communities around them because the properties remain vacant or underutilized. The contamination of the sites precludes redevelopment of the property for beneficial economic uses.

One barrier to redevelopment of these sites has been the lack of financial means for site cleanup (either removal or capping) to meet public health standards set by the state's Environmental Protection Agency (Iannone, 1997). Through the 1990s, despite changes to clean up standards that were more favorable to redevelopment, local redevelopment agencies and private property owners often found that traditional sources of funding for redevelopment were insufficient to meet the cleanup costs and that banks often considered projects too risky for financing, given the uncertainty of the levels of contamination until expensive scientific studies could be completed (Murphy, 1997). The state of Ohio convened an urban revitalization taskforce in the late 1990 s that sought to identify mechanisms to encourage investment in urban areas. That taskforce identified brownfields as a major land use problem and financing of the cleanup of brownfields as a key impediment to redevelopment and investment (Urban Revitalization Task Force, 2000).

In 2000, the Ohio legislature created the Clean Ohio Revitalization Fund to provide financing for the cleanup of brownfield sites in urban, suburban, and rural areas of the state. General obligation bonds for \$200 million over a four-year period subsequently won the approval of voters. The legislation also established the Clean Ohio Council to oversee grant distribution to local communities. Responsibility for implementation and administration of the brownfield component was assigned to the Ohio Department of Development (ODOD) as lead agency, with the Ohio Environmental Protection Agency (OEPA) and the Ohio Public Works Commission (OPWC) playing key roles as well. The nineteen district Public Works Integrating Committees of the OPWC, which had for years prioritized and made funding awards for local infrastructure projects (roads, bridges, and other public works projects) were designated as the entities that would recommend to the Clean Ohio Council which communities would receive cleanup awards. The Public Works Integrating Committees consisted of representatives from local government public works agencies, county commissioners, county engineers, township trustees, municipal government associations, and private sector entities in the land redevelopment business. These were not citizens or residents, but stakeholders familiar with government programs.

\section{Ohio Coastal Resources Management Training Program}

Ohio's northern boundary is Lake Erie, which is surrounded as well by three other states (New York, Pennsylvania, and Michigan) and the province of Ontario, Canada. Each state on the Great Lakes coast is eligible for federal program funding upon completion of a coastal management plan (United States Congress, 1972, 1996). Ohio's program was finished and accepted by the federal government in 1998. Ohio is unique in the Great Lakes basin, however, in that it is home to a National Estuarine Research Reserve (NERR) site at Old Woman Creek, a small tributary and estuary located between Toledo and Cleveland. The site, which is also a state nature preserve, is managed jointly by the National Oceanic and Atmospheric Administration (NOAA) and the Ohio Department of Natural Resources (ODNR).

One of the key functions of the NERR sites is to work with state and local agencies to bring the results of federallyfunded scientific research about coastal processes to local decision makers who influence conditions of coastal resources. The assumption is that through enhanced knowledge of resource conditions and function, local decision makers will make decisions more favorable to the resource base. Coastal resource decision makers include government agency staff at local and regional levels, local and regional elected officials, industrial leaders, farmers, marina operators, fisheries workers, tourism and recreational 
facility operators, and other landowners in the coastal area (Great Lakes Environmental Finance Center, 2003). Each type of decision maker is guided by particular interests, responsibilities, and authority as these are shaped by the institutional, economic, and ecological conditions in a given coastal area. These decision makers shape land use, economic development, location of infrastructure, coastal development, and land management practices.

An important part of the outreach function of the NERR center involves the development of training and other educational programs. Beginning in 2002, NOAA required its NERR sites to develop Coastal Training Programs (Great Lakes Environmental Finance Center, 2004). In response, the Ohio Coastal Resources Management Training Program was formed as a partnership between NOAA, ODNR, and the Ohio Sea Grant Program. These agencies all play major roles in providing or supporting informational outreach and training programs relevant to coastal and watershed management in the Lake Erie basin. Part of the Coastal Training Program development required an assessment of local decision-maker needs for training, identification of the modalities by which local decision makers gain information about effective coastal management practices and their preferred learning modalities, and whether and how they incorporate scientific and management knowledge of coastal resources into their decision-making practices.

\section{The Focus Group Processes and Results}

\section{Clean Ohio Revitalization Fund}

The ODOD elected to hold focus group sessions with members of the Public Works Integrating Committees to develop a detailed set of decision rules by which monies from the fund would be awarded. These stakeholders were asked to set program priorities, develop the criteria by which to evaluate proposals for funding awards, and develop the scoring rubric that would be used to rank funding applications. Comfort (1981) called this type of process "specification," in which the goals of a policy are defined and those developing the programs give meaning to the policy itself. Williams and Elmore (1976) considered specification the process of translating a decision with imprecise operational language into a set of useful guidelines for the field. Although specification could have been accomplished by technical staff within the agency, ODOD sought a collaborative, co-productive process to ensure that the process for distribution of funds would be viewed as le- gitimate across a disparate set of stakeholders who might eventually be competing for funding awards.

Nineteen focus groups were held throughout rural, suburban, and urban locations. The sessions were designed to convey information on the goals, objectives, and requirements of the Clean Ohio Revitalization Fund under the authorizing legislation to the participants, identify their expectations with regard to the program, explore their recommendations for the local Clean Ohio grant-making process, and identify the local priorities for the Clean Ohio Revitalization Fund program among the six decisionmaking criteria identified in the program legislation. The ODOD and its project staff sought to create an interactive environment that would enable local future implementers (the Public Works Integrating Committees) to develop the selection methodology by which cleanup grants would be awarded.

At each session, one or more of three ODOD staff members assigned to the program presented information about the Fund, using the same protocol each time for consistency of information. One or both of the project directors and managers facilitated each of the focus groups, and the same format and questions were asked to maintain consistency and reduce bias. Each focus group was conducted in a 90-minute format; group size ranged from eight to 23 participants. More than 200 members of Public Works Integrating Committees across nineteen districts participated in the sessions. Two types of data were collected during the focus group sessions. Qualitative data consisted of stories and examples of experiential events concerning brownfields and infrastructure funding relayed by the participants. Participants also spent time discussing their understanding of the language of the legislation in a process designed to reach some consensus for definitions that would be used in program implementation, which was followed by a tabulation of preferences.

The outcome of the focus groups was a program that has been used for three years to award monies for brownfield cleanup and redevelopment. The goals and objectives of the legislation were "specified" into a program through the deliberative process in the focus groups, beginning with stakeholder expansion of the definitions of categories used to evaluate proposals in the legislation. The process revealed a high level of consensus across the nineteen groups that the economic development and environmental benefits aspects of the program were of equal importance and needed equal weight in the award evaluation process. Stakeholders across the groups emphasized the need for the 
state to honor any local funding recommendations developed and to bring the benefits of the program to all lowincome communities, whether rural or urban. They urged to state to avoid an urban bias in the distribution of funds through the program.

There was a significant degree of congruence among the focus groups in how they defined program criteria and priorities, which is not surprising given many years of work together in the context of public works funding committees. Their responses also illustrated pre-existing tensions between agencies, geographic regions (north, south, east, west, and rural/urban) of the state, between the state and local levels, and between urban and rural participants.

The participants in the focus groups (the members of the district Public Works Integrating Committees) were consulted by the state's Department of Development after each year of implementation of the funding program as well. They suggested modifications to the scoring rubric they had developed, so that it led to cleanup projects with a higher probability for leading directly to redevelopment projects. In this way, the stakeholders became the basis of implementation of the program they helped design (Kellogg, O’Brien, and Toth, 2006).

\section{Coastal Resources Management Training Partnership}

As previously mentioned, NOAA requested that each of its NERRs sites develop a coastal training program with its state and local partners. A first part of the Coastal Resources Management Training Program development process identified the current market for training opportunities regarding coastal resources management in the Ohio Lake Erie basin (Kellogg et al., 2005). A second phase of the strategic planning process asked for an assessment of the training needs among local decision makers. A series of focus groups was convened across the Ohio Lake Erie basin to assess the gaps between currently available and desired knowledge, skills, and tools needed by local decision makers for effective coastal decision making; to identify potential strategies and tools for filling those gaps; and to determine the attitudes and motivation of these officials toward enrolling in training sessions.

Seven focus groups were held. Six focus groups were convened with a multidisciplinary representation of coastal decision makers, including elected officials (mayors, zoning administrators, township trustees, county commissioners, and city and village council members) and staff from a broad range of government administrative agencies (city, county, and metropolitan planning engineers' offices; economic development and tourism; port authorities; health departments; and sewer and water districts). A seventh focus group consisted of staff from twelve organizations that provide training broadly related to coastal resources management in the Ohio Lake Erie basin. For all seven processes, the goal was to involve participants who could speak authoritatively about their knowledge and information needs and the challenges they faced in their professional roles. Seventy-eight percent had more than ten years of work experience in their field, representing a range of positions in their organizations, including directors (28\%), elected and appointed officials (31\%), managerial (15\%), supervisory $(4 \%)$, and technical staff $(13 \%)$.

Focus group participants were identified by telephoning the main offices of several trade-based and nongovernmental organizations and associations (engineers, municipal leagues, managers associations, county commissioners associations, etc.). They were asked to identify members who were in leadership roles and were familiar with land use and other issues related to coastal and watershed management. The facilitation project staff contacted 643 recommended coastal decision makers by telephone over a few weeks' period and asked them to be part of a focus group. A mailed letter of invitation was then sent to those who agreed to participate. The total number of participants was 57; the average group size was between eight and nine.

The focus groups were conducted across the Lake Erie basin in regions demarcated by criteria of the type of water resource (lake/coastal zone versus watershed), rural versus suburban versus urban location, and agricultural- versus non-agricultural-dominant economic base. The size of the regions for the focus groups was determined by identifying the expected number of potential training participants in each county, based on the likely number of elected and appointed officials for a given population as a proxy (Ohio Department of Development, 2000) and by assembling counties into areas to achieve relatively the same number of potential participants in training programs for each market share area. The same facilitator conducted each of the seven focus group sessions, and the same format and questions were asked to maintain consistency and reduce bias. Data were collected using two types of methods: a brief questionnaire administered prior to the beginning of the session and a structured interactive question and discussion session, which was recorded through newsprint and computer-based real-time notetaking. 
The information obtained through the focus group process was used to develop the strategies for additional training programs by the client organizations. Notes were synthesized by the facilitation team and thereafter systematically reviewed. We counted the frequency by which themes were identified and the relative amount of discussion spent on a given theme (which was taken as a proxy of participant interest and importance). Several themes were identified from the participants' conversations about both core knowledge needs and the information delivery mechanisms they found most useful. The decision makers were interested in economic impacts and the value of coastal and watershed stewardship, how to use zoning to protect these resources, and additional funding sources to pay for the use of best management practices. They were somewhat more interested in access to information than in formal training programs per se, and wanted training sessions to be targeted at their particular local and regional needs. They suggested that an information clearinghouse, containing Web resources, access to professionals, and access to best practices used by peers in Ohio would most greatly assist their efforts to respond to regulations and enhance their coastal and watershed resources management. There was a high level of consensus across these six focus groups on their knowledge needs and preferred information delivery modalities.

In contrast, participants in the focus group of training providers concentrated on delivery of scientific knowledge to decision makers and the need to expand the local or regional perspective these decision makers have to a basinwide appreciation of ecosystems. This group did also, however, stress the need to facilitate knowledge transfer through some sort of clearinghouse function across a network of training providers and professionals with expertise in coastal resources management.

\section{Observations and Key Lessons}

This section describes the patterns of benefits and challenges to agency needs posed by the use of focus groups instead of other information-gathering participation techniques or other types of collaborative processes, as experienced in these two cases. We note similarities and differences between the two cases as well and describe how differences were addressed through design of the focus group process for each. The expected benefits accrued from stakeholder involvement in the coproduction of agency programs were (1) creation of a more robust knowledge base to increase program effectiveness; (2) enhanced agency understanding of stakeholder expectations about the program and the appropriate role for agency; (3) increased implementation feasibility as influenced by stakeholder capacity, political legitimacy, and a constituency interested in the outcomes of the program; and (4) improved agency capacity. Our description also provides some guidance or lessons for agencies seeking more collaborative processes with stakeholders.

\section{Effective Programs}

Effectiveness includes ensuring that the beneficiaries entitled to access the program are reached and that the program actually addresses their needs (Nichols, 2002). By including stakeholders in the development of the programs and their implementation rules, the agencies ensured to a fuller extent that the coastal management program would respond to their knowledge and training delivery needs, and that the brownfield financing program would result in money awarded to applicants who had the capacity to ensure the cleanup of land for redevelopment.

Although the two focus group processes we compared were somewhat different in objectives and process (developing decision rules to satisfy each agency's mandate for distribution of funds and conducting a needs assessment to design collaborative training programs), in both cases the agencies wanted to know how these experienced decision makers perceived the new administrative programs and, in their experience, how the programs would respond most effectively to their needs. In both cases, the process needed to provide guidance to the agencies to help reconcile expectations for programs based on scientific/technical information and local decision makers' needs to make the programs more relevant.

Why were focus groups chosen for this objective when other methods of data collection were possible? Although not of the highest importance, efficiency under constrained resources was a key concern and benefit. Based on prior experience, the team was convinced that this method was the most appropriate for gathering a large amount of qualitative information in a short amount of time. Use of a survey instrument would have been more costly and would not have achieved the collaborative goals. Interviews would have taken more staff time to coordinate and more use of travel expenses; in the time it takes to conduct one interview, the team was able to conduct a focus group to get the perceptions of six, ten, or fifteen people. Individual interviews are labor-intensive and inexpedient for the number of stakeholders the agencies wanted to reach. 
Interviews also do not generate information that arises from participant interaction. There were also not resources or time to institute a long, ongoing taskforce or advisory committee for a collaborative process. Rule-making for the Clean Ohio Revitalization Fund program needed to be in place to conform to state budget cycles and timely implementation of the law. In the coastal management training program, state agencies had programmatic deadlines to ensure approval of their plan for training to conform to the NOAA funding cycles. Foremost, the information sought was in great part the perceptions of the participants rather than an objective measure of "the best program." Our experience confirms that focus groups are a very appropriate qualitative methodology in this type of setting (Dreachslin, 1999).

Focus groups also allowed for three kinds of data to be collected simultaneously: information from individuals, information arising from the group's interaction, and information about the interaction itself (Duggleby, 2004). In our cases, individual data were generated in two ways: through recording the remarks of participants during the discussion and through a quantitative survey that was administered to individual participants at each session and then used to generate a profile of participants and get their responses. The individual comments revealed the lived experiences of stakeholders, relating their first-hand knowledge about conditions the agencies wanted to address. The write-in section on the survey session also resulted in additional information on the project strategy not planned for by the agency. The use of the questionnaire helped to validate the data collected through the group discussion, because some questions were used in both methods.

At the group level, the use of focus groups allowed development of a more nuanced and complete response to administrative program development and implementation than was likely from surveys or individual interviews. The focus groups generated a multiplicity of views on the spot; information emerging from such interaction among participants cannot be replicated using survey methods. The interaction between stakeholders with different backgrounds and expertise allows a facilitator to hear from all different sides. In our experience, new information was revealed that no one had thought of previously. We observed and recorded spontaneous reactions to issues and events that arose in the course of the focus groups.

Convening the focus groups in stakeholder communities improved our understanding of the diversity of stake- holder needs and expectations. In both the Clean Ohio Revitalization Fund (conducted across the state) and the coastal resources training program (conducted across the Lake Erie basin) development processes, differences in technical and cultural expectations came to light. This type of knowledge is only generated as a result of group interaction and is not likely to be found using surveys. Because the participants in the focus groups were carefully chosen to represent a cross-section of stakeholders and beneficiaries for the two programs, we are confident that the perceptions and opinions we recorded would likely be replicated among other sets of similar participants.

Finally, in addition to the expressed views of the participants, the observation of group dynamics or patterns of interaction is important information as well (Duggleby, 2004), providing insight about the situation or context in which the administrative program will be implemented. This aspect of group information points out several challenges inherent in the focus group process related to the generation and collection of useful information. Our facilitators, who knew about the history, political context, and technical concerns upon which the focus groups were conducted, could assess some of the underlying issues in terms of what the stakeholders wanted and the social dynamics that shaped their responses. For example, longstanding tensions in Ohio between urban and rural communities came out in the Clean Ohio Revitalization Fund focus groups, and facilitators needed to take extra care to allow participants, whether rural or urban, to see the benefits that might accrue to each from the new program. Based on our experience, we strongly suggest that in environmental and resource management contexts, facilitators need to have substantive knowledge of both the environmental problem or concern and the regulatory and organizational context leading to the focus group. In our experience, ignorance of the technical and administrative context by the facilitator can result in inaccurate or incomplete information and suboptimal program design.

The group dynamic itself can be a challenge. Contentious groups can be difficult to manage. Sometimes the participants' true feelings emerge more strongly than anticipated; maintaining control and staying on the mark can be difficult, but is necessary. In our experience, an appeal to the role of the facilitator as a neutral party who must keep the conversation on time and get through the questions, objectives, and purpose for holding the session can diffuse contentiousness among members to allow for more fruitful discussion. Properly managed, the initially contentious groups-because they were engaged from the start of pro- 
gram development-can result in important information for the agency in terms of understanding the underlying needs and expectations of stakeholders. Generally, people are not unruly, however; they are being asked to participate, to be "players," so they don't want to appear unreasonable. For example, the brownfield program development process was potentially very contentious because it was about how to distribute money directly from the state agency to local communities. The facilitator spent more time in this situation discussing the needs of all the communities, allowing the participants to hear responses from different perspectives. No focus group sessions ended on a contentious note. This experience supports suggestions by Meidinger (1987) that the expectation of the need for ongoing cooperation in the future tempers individual behavior to fit in with the dominant group. In our case, the members in the focus group knew they were going to meet periodically to review the results of the program over the next several years.

\section{Enhanced Civic and Administrative Capacity}

From a normative perspective, participation in administrative processes has been seen as an affirmation of democratic principles (Barber, 1981; Stivers, 1990). Participation creates a more inclusive democracy by offering stakeholders the opportunity to present facts and arguments to an agency (Harter, 1982), broadening public discourse and enhancing public understanding of public issues (Wiig, 2002).

These were the outcomes desired by agencies in both programs, and the focus groups provided deliberative processes that supported the capacity for these outcomes. Each agency sought information from stakeholders, but the focus groups were also an opportunity to share technical and administrative information with the stakeholders, who would either be future users or implementers of the program under design. In the focus groups for the two programs, interaction occurred among stakeholders, not only providing information for the agencies, but allowing the participants to hear each other, too. Group interaction builds a shared knowledge base, shared language, and perhaps a shared perception about the program being discussed. Creating a shared knowledge base and a shared understanding about program design and implementation among different constituents and stakeholders who would be a part of implementation was a key objective for the agencies to ensure creation of local capacity to participate in the programs.
For example, the use of the Public Works Integrating Committees in the Clean Ohio Revitalization Fund program design process seemed illogical at first to the members of the Public Works Integrating Committees, who were familiar with infrastructure but commented that they didn't think they had the expertise to judge brownfields or assess environmental criteria. Although only a few of the Public Works Integrating Committee members were environmental engineers, most members had a deep knowledge of local issues and local needs. They had participated in over ten funding cycles to distribute money for infrastructure projects for the public works commission programs and understood the relationship between infrastructure, land, and economic development. They had also been using a selection method (a scoring rubric) that was similar to what the brownfield legislation suggested and to what ODOD staff intended for the program. Participation in the focus groups ensured they all heard the same information from the agency and understood the requirements of the legislation from the beginning. Through the discussion, they clarified the differences between the public works program and the new program, understanding their role in the process. They were then able to focus on developing the rules for the program, including the scoring rubric that would be used to distribute state monies (Kellogg, O’Brien, and Toth, 2006).

The same process occurred in the coastal resources management focus groups. In the case of the coastal resources management program, participants were local decision makers who ultimately were the target of the agencies' training and outreach programs. Effective program design was, to the agency partners, predicated on developing the best modes for delivery of information and addressing the information needs among decision makers, as they saw them. Otherwise, the program was likely to be underutilized. Participants (local officials and other important stakeholders) were unfamiliar with the new partnership that had been formed between existing state coastal management programs and the federal NERR site. One objective of the federal agency was to build collaborative networks among training users and providers. The focus groups allowed the agencies to inform the participants about their partnership and their efforts to strengthen the flow of information and technical assistance. The focus groups also afforded a first opportunity to convey important scientific information about coastal processes to the participants, something that was a high priority for the agencies involved (Kellogg et al., 2005).

Participants in the coastal management focus groupswho were decision makers in six focus groups and training 
providers in one-also learned about the activities of their colleagues in several different regions within the Ohio Lake Erie basin. In addition, the process gave participants an opportunity to understand how the issue related to themselves and to each other. Through their discussion, the focus group participants recognized the value of this peerto-peer relationship, which formed the basis of one of the recommended strategies for peer-to-peer mentoring as part of the coastal training partnership programs. This creation or strengthening of relationships and recognition of the ongoing benefits that might accrue from them is one way the use of focus groups in social science research differs from their use in marketing studies. In the program development processes, agencies were not only trying to get feedback on a "product," but they asked participants to help design something they could be a part of in the future. Building these peer relationships was not a similar concern in the Clean Ohio Revitalization Fund program, because participants had collaborated in the past on the public works committees.

Overall, the focus groups proved to be effective modalities for introducing complex scientific and regulatory concepts to the participants who eventually would become involved in program implementation. The discussion among participants was a way to push them to identify more fully how the programs should be designed and implemented, because it let the stakeholders understand what the programs had to accomplish and how that could best be done. In the Clean Ohio Revitalization Fund program, the participants were able to develop a complex scoring rubric that was used (with minor changes in point priorities) for three years (Kellogg, O'Brien, and Toth, 2006). As a result of the coastal management training focus groups, a joint state-federal program was instituted in the Lake Erie basin (National Estuarine Research Reserve/Ohio Coastal Management Program, 2007).

The challenges associated with developing capacity through a shared knowledge base were most directly related to the different technical expertise levels among participants. The facilitators found that sometimes participants seemed intimidated by those with different expertise. It was then the responsibility of the facilitator to solicit input from all people, to provide a comfort level for all participants that would stimulate discussion. This experience, as well, points to the need for facilitator(s) with both process and technical knowledge.

In our cases, agency staff capacity for program design and implementation was also increased through the focus group process. Development and implementation of a new administrative program requires an educational process within the implementing organizations and an adoption of new tasks (Sarbaugh-Thompson, 1998). This occurred for two reasons: reshaping interagency networks (Hall and O'Toole, 2004) and clarifying the respective roles of the agencies that were part of the program development process (Spicer and Terry, 1996). In the Clean Ohio Revitalization Fund example, the legislation explicitly mandated creation of a programmatic network of state agencies-development, environmental protection, and public works. The roles that the various agencies would play were specified somewhat in the legislation, but it became apparent that their relative influence on the process was equivocal, meaning that the relationship of these organizations was not necessarily straightforward for the Clean Ohio Revitalization Fund program. The development agency and the public works commission typically seek to stimulate new investment in localized areas for business creation, relocation, and infrastructure development, respectively. Each organization, however, is dependent upon permitting and funding by the environmental protection agency. The ODOD objectives were to develop a detailed set of decision rules by which monies from the fund would be awarded. One initial source of confusion was who would control the program, given the authority placed in ODOD by the legislation, coupled with the central decision-making role that the Public Works Integrating Committees would have in prioritizing local applications for money. The outcome of the focus groups raises the possibility of changed interaction among the agencies that were required by law to implement the program. The scoring rubric developed through the focus group process served to "take the language that is contained in law and turn it into something concretely meaningful that can be understood and implemented by the parties involved" (Hall and O'Toole, 2004, p. 198). In the Clean Ohio Revitalization Fund experience, ODOD used the focus group process as a way to assert its role as primary lead agency for the program.

In the coastal training case, NOAA needed a buy-in of state training providers to create a network of educational/ outreach opportunities for decision makers. The focus groups identified needs for training and the "value added" that might accrue to state agencies by collaborating with NOAA in achieving their agency mandates.

The temporary interactions during focus groups also led to more cooperation and communication among the agencies as a result of their participation in the focus groups. In the Clean Ohio Revitalization Fund process, agency people 
noted at the end of the focus groups that once they had participated in one process, they recognized the benefit of having a similar process for designing other programs. Prior to the brownfield refinancing program, ODOD conducted surveys as input to designing administrative programs, so at first, staff members were skeptical. As they observed the focus group results, however, they began to trust the process and see the benefits of the information that came out of the interaction among participants. This was facilitated because we returned the summaries and results of the focus groups to them for a second round of comments. The agency staff became more willing to adopt this as a mechanism for other programs. The focus groups are probably not as effective as the sustained longer term interaction from using an ongoing taskforce or advisory committee; however, based on subsequent years of updates and implementation of the programs, the focus groups initiated a more collaborative inter-agency relationship that has helped improve implementation of the brownfield law.

In the coastal management case, the focus group process identified what "value added" to training programs could be provided by the respective agencies, federal and state. An initial market study had identified training providers in the basin (Kellogg et al., 2005) and the purpose of the focus groups was to identify how the coastal management training partnership could build on the programs of these providers.

\section{Building Legitimacy for the Programs}

A final important outcome in using focus groups-as opposed to surveys - is to build a sense in the community and among stakeholders that the process and design of the program is legitimate. Part of an agency's responsibility is to ensure that the programs it administers are perceived as both effective and fair among potential beneficiaries or end users (Nichols, 2002). In our case, the concern with legitimacy signifies, to some degree, the need to balance the authority of science or technical information driving the process (what brownfields could be efficiently cleaned up or would have the greatest effect on redevelopment, and what information local decision makers needed to be the coastal resources stewards) with inclusion of the political realities that shaped the process to distribute government funds and gain access to programs.

Stakeholder perception that a program is not equitable can reduce the legitimacy of the program among potential beneficiaries, which then decreases their participation
(Ashforth, 1992). The issue of fairness was less a concern in the coastal management training program, but was very central to program development for the Clean Ohio Revitalization Fund. There is a long-standing history of tension between different geographic areas of the state, including between rural and metropolitan areas and between communities in the Ohio Lake Erie basin and the rest of the state. Through the focus groups, the stakeholders found that, although they were from different areas in the state, they had the same or similar issues and concerns. The focus groups provided a mechanism through which the agency could ensure that stakeholders understood and gave their approval to the funding allocation process that would be used, in the hope that if any geographic patterns to funding arose, the stakeholders would not assume the patterns were a result of this history or of political bias in the program. This hopefully would ensure stakeholder "buy-in" for the program and its administration. More broadly, the focus groups provided a setting that convened stakeholders with different perspectives, and while that implies the potential for conflict, it also provides a mechanism for resolving key issues early on, and at times building consensus. Ensuring robust participation in the program was critical for enhancing the program's effectiveness, i.e., land cleaned up and redeveloped. In three years of implementation, continued participation in the Clean Ohio Revitalization Fund program by Public Works Integrating Committee members to review the scoring rubric, along with continued participation in the program by localities across the state, indicates an overall sense of program legitimacy.

In the case of the coastal management training program, various combinations of partners had worked together on smaller efforts in the past, but the level of collaboration to ensure timely development of the plans for coastal training in response to the NOAA requirements was new. Although the agency partners did not participate directly in the focus groups, reporting back to them in great detail gave them a more nuanced sense of what their program needed to address. In the brownfield cleanup funding focus groups, agency staff observed the processes and attended frequent briefing sessions with the research team as well. The legislation creating the program gave authority to one of the agencies, but other agency staff, which had in other programs been afforded a higher level of control, also had a role to play. The focus groups allowed the ODOD to reassure the other agency partners of their roles while clarifying its central role in the development and administration of the program and building a constituency among the stakeholders for the agency's central role. 
To summarize the difference over time put in place by the focus group processes, the Clean Ohio Revitalization Fund funding award program was reviewed annually for three years to renew the policy discussions. The information from implementation was used to redesign award scoring rubric, which, in turn, changed the distribution of funds. For the coastal management program, one series of focus groups was developed for an umbrella program to add higher value to the available training opportunities in the Lake Erie basin. The agency needed information about existing training and how the partnership with the federal government could fill in gaps and coordinate across existing training programs to make training more effective and accessible to decision makers.

The greatest challenge to the use of focus groups in both these cases was that focus groups, in contrast to ongoing deliberative processes such as taskforces or advisory committees, provide less time for interaction. They are a snapshot of current views, or a series of snapshots, which cannot possibly provide an experience as intensive as ongoing development of shared meanings through many interactions over time. Still, in cases where agencies need to gather information and build collaborative capacity through their program development process in a relatively short time period, our experience suggests that focus groups can provide a useful method.

Given our experiences, a mention of future research needs and limitations is in order. We suggest that a formal follow-up after several years of implementation of programs to see the more lasting effect of the collaborative program design process would help identify shortcomings in the focus group approach. We also suggest that an investigation of how new technologies, including the Internet, can be used by similar agencies to construct online or virtual focus groups (Chase and Alvarez, 2000) and to facilitate the networks of stakeholders and agency staff brought together by these programs may shed light on the continued operation of agency and stakeholder networks put in place through the cases described here.

\section{References}

Albrecht, T., G. Johnson, and J. Walther. 1993. Understanding Communication Processes in Focus Groups. In Successful Focus Groups: Advancing the State of the Art, D. Morgan, ed. Sage Publications, Newbury Park, CA, 51-64.

Ashforth, B. 1992. The Perceived Inequity of Systems. Administration and Society 24(3):375-408.
Barber, D. 1981. Citizen Participation in American Communities: Strategies for Success. Kendall/Hunt, Dubuque, IA.

Bellinger, D., K. Bernhardt, and J. Goldstucker. 1976. Qualitative Marketing Research. American Marketing Association, Chicago.

Booher, D. 2004. Collaborative Governance Practices and Democracy. National Civic Review (Winter):32-46.

Chase, L., and J. Alvarez. 2000. Internet Research: The Role of the Focus Group. Library and Information Science Research 22(4):357-369.

Comfort, L. K. 1981. Goals and Means: The Problem of Specification in the Development of Effective Public Policy. Administration and Society 13(1):77-108.

Connick, S., and J. Innes. 2003. Outcomes of Collaborative Water Policy Making: Applying Complexity Thinking to Evaluation. Journal of Environmental Planning and Management 46(2):177-197.

Cooper, T., and P. Kathi. 2005. Neighborhood Councils and City Agencies: A Model of Collaborative Coproduction. National Civic Review (Spring):43-53.

Desario, J. and S. Langton, eds. 1987. Citizen Participation in Public Decision Making. Greenwood, Westport, CT.

Desvousges, W., and V. Smith. 1988. Focus Groups and Risk Communication: The "Science" of Listening To Data. Risk Analysis 8:479-484.

Dreachslin, J. 1999. Focus Groups as a Quality Improvement Technique: A Case Example from Health Administration Education. Quality Assurance in Education 7(4):224-233.

Duggleby, W. 2004. Methodological Issues in Focus Group Data Analysis. Nursing and Health Sciences 6(2):161.

Durant, R., Y. Chun, B. Kim, and S. Lee. 2004. Toward a New Governance Paradigm for Environmental and Natural Resources Management in the 21st Century? Administration and Society 35(6):643-682.

Edelbos, J., and E. Klijn. 2005. Managing Stakeholder Involvement in Decision Making: A Comparative Analysis of Six Interactive Processes in the Netherlands. Journal of Public Administration Research and Theory 16:417-446.

Fischer, F. 1993. Citizen Participation and the Democratization of Policy Expertise: From Theoretical Inquiry to Practical Cases. Policy Science 26:165-187.

Great Lakes Environmental Finance Center. 2003. Coastal Resources Management Training Needs Assessment: A Report on Seven Focus Groups in Northern Ohio. Cleveland State University, Cleveland, OH.

Great Lakes Environmental Finance Center. 2004. Analysis of the NERRs Coastal Training Program Documents. Cleveland State University, Cleveland, $\mathrm{OH}$.

Grin, J., and H. Van de Graaf. 1997. Implementation as Communicative Action. Policy Sciences 29(4):291-319.

Grunig, L. 1992. Matching Public Relations Research to the Problem: Conducting a Special Focus Group. Journal of Public Relations Research $4(1): 21-43$.

Hall, T., and L. O’Toole. 2004. Shaping Formal Networks through the Regulatory Process. Administration \& Society 36(2):186-207.

Harter, P. 1982. Negotiating Regulations: A Cure for the Malaise. Georgetown Law Journal 71(1):1-118.

Heikkila, T., and A. Gerlak. 2005. The Formation of Large-Scale Collaborative Resource Management Institutions: Clarifying the Roles of Stakeholders, Science and Institutions. The Policy Studies Journal 33(4):583-612. 
Higgenbotham, J., and K. Cox. 1979. Focus-Group Interviews: A Reader. American Marketing Association, Chicago.

Iannone, D. 1997. Creative Financing Strategies for Redeveloping Brownfields. In Brownfields: A Comprehensive Guide to Redeveloping Contaminated Property, T. Davis and K. Margolis, eds. American Bar Association Publishing, Chicago, 87-99.

Kahan, J. 2001. Focus Groups as a Tool for Policy Analysis. Analyses of Social Issues and Public Policy 1(1):129-146.

Kaplowitz, M., and J. Hoehn. 2001. Do Focus Groups and Individual Interviews Reveal the Same Information for Natural Resource Valuation? Ecological Economics 36:237-247.

Kellogg, W. 1998. Adopting an Ecosystem Approach: Local Variability in Remedial Action Planning. Society and Natural Resources 11(5):465-483.

Kellogg, W., K. O'Brien, and K. Toth. 2006. The Use of Constituent Focus Groups for More Effective Program Planning and Management: A Case Study of the Clean Ohio Revitalization Fund. Public Performance \& Management Review 30(1):96-121.

Kellogg, W., M. Tevesz, C. Robey, K. O’Brien, M. McGoun, K. Toth, and D. Baracskay. 2005. Training Needs of Coastal Resources Decision Makers in Ohio's Lake Erie Basin. Coastal Management 33(3):335-351.

Knodel, J. 1993. The Design and Analysis of Focus Group Studies: A Practical Approach. In Successful Focus Groups: Advancing the State of the Art, D. Morgan, ed. Sage Publications, Newbury Park, CA, 35-50.

Koontz, T., and E. Johnson. 2004. One Size Does Not Fit All: Matching Breadth of Stakeholder Participation to Watershed Group Accomplishments. Policy Science 37:185-204.

Kreuger, R. 1994. Focus Groups, 2nd Edition. Sage, Thousand Oaks, CA. Kreuger, R., and M. Casey. 200o. Focus Groups: A Practical Guide for Applied Research, 3rd Edition. Sage, Thousand Oaks, CA.

Kweit, M., and R. Kweit. 1981. Implementing Citizen Participation in a Bureaucratic Society: A Contingency Approach. Praeger, New York.

Leach, W., N. Pelkey, and P. Sabatier. 2002. Stakeholder Partnerships as Collaborative Policymaking: Evaluation Criteria Applied to Watershed Management in California and Washington. Journal of Policy Analysis and Management 21(4):645-670.

Meidinger, E. 1987. Regulatory Culture: A Theoretical Outline. Law and Policy 9(4):355-386.

Murphy, M. 1997. Brownfields Sites: Removing Lender Concerns as a Barrier to Redevelopment. In Brownfields: A Comprehensive Guide To Redeveloping Contaminated Property, T. Davis and K. Margolis, eds. American Bar Association Publishing, Chicago, 100-120.

National Estuarine Research Reserve/Ohio Coastal Management Program. 2007. http://www8.nos.noaa.gov/publicnerrs/training.aspx.

Newman, J., M. Barnes, H. Sullivan, and A. Knops. 2004. Public Participation and Collaborative Governance. Journal of Social Policy 33(2):203-223.

Nichols, L. 2002. Participatory Program Planning: Including Program Participants and Evaluators. Evaluation and Program Planning 25:1-14.
Ohio Department of Development. 2000. Profiles of General Demographic Characteristics: 2000 for Ohio's Counties, http://www. odod.state.oh.us/osr/20oodemch.htm. Accessed August 15, 2002.

Polanyi, M. 1966. The Tacit Dimension. Anchor Books, New York.

Randolph, J. 2004. Collaborative Environmental Management and Public Participation. In Environmental Land Use Planning and Management, Island Press, Washington, DC, 53-74.

Reich, R. 1985. Public Administration and Public Deliberation: An Interpretive Essay. Yale Law Journal 94:1617-1641.

Rich, R. 1986. Neighborhood-Based Participation in the Planning Process: Promise and Reality. In Urban Neighborhoods: Research and Policy, R. B. Taylor, ed. Praeger, Westport, CT.

Sarbaugh-Thompson, M. 1998. Change from Below: Integrating Bottom-Up Entrepreneurship into a Program Development Framework. American Review of Public Administration 28(1):3-25.

Seidel, J., and V. Clark. 1984. The Ethnograph: A Computer Program for the Analysis of Qualitative Data. Qualitative Sociology 7(1/2):110-125.

Spicer, M., and L. Terry. 1996. Administrative Interpretation of Statues: A Constitutional View on the "New World Order" of Public Administration. Public Administration Review 56(1):38-47.

Stivers, C. 1990. The Public Agency as Polis: Active Citizenship in the Administrative State. Administration and Society 22(1):86-105.

Thomas, J. 1993. Public Involvement and Governmental Effectiveness: A Decision-Making Model for Public Managers. Administration and Society 24(4):444-469.

United States Congress. 1972, 1996. Coastal Zone Management Act (1972) and PL 104-150. Washington, DC.

Urban Revitalization Task Force. 200o. Ohio Urban Revitalization: Policy Agenda and Task Force Report. Ohio Department of Development, http:// www.odod.state.oh.us/urtf/pdf. Accessed August 5, 2006.

Vroom, V., and P. Yetton. 1973. Leadership and Decision Making. University of Pittsburgh Press, Pittsburgh.

Wiig, K. 2002. Knowledge Management in Public Administration. Journal of Knowledge Management 6(3):224-239.

Wilkinson, S. 1998. Focus Groups in Feminist Research: Power, Interaction and the Construction of Meaning. Women's Studies International Forum 21(1):111-125.

Williams, W., and R. Elmore, eds. 1976. Social Program Implementation. Academic Press, New York.

Wondolleck, J., and S. Yaffee. 200o. Making Collaborations Work: Lessons from Innovation in Natural Resource Management. Island Press, Washington, DC.

Yanow, D. 1993. The Communication of Policy Meanings: Implementation as Interpretation and Text. Policy Sciences 26:41-61.

Submitted May 16, 2006; revised October 1, 2007; accepted October 2, 2007. 